\title{
A Study of Dylan Thomas's Poetry
}

\author{
Ch.Nagaraju ${ }^{1}$, K. V. Seshaiah ${ }^{2}$ \\ Asst. Prof., Dept of Science and Humanities, N.B.K.R.I.S.T. Vidyanagar, S.P.S.R. Nellore, A.P., India \\ Asst. Prof., Department of Science and Humanities, YITS, Tirupathi, Chittoor, A.P., India
}

\begin{abstract}
Dylan Thomas is one of the writers who has often been associated with Welsh literature and culture in the last sixty years. He is possibly the most notable Welsh author. Fortunately, it is mainly his literary work, and not his tumultuous lifestyle, that is still associated with him. The analysis of some of his poems mirrors his sincere relationship to Wales. In 1937 he married to Caitlin MacNamara who gave birth to three children. These circumstances indicate a typical British conservative and straight forward approach to family life. Dylan Thomas was influenced in his writing by the Romantic Movement for the beginning of the nineteenth century and this can be seen in a number of his best works. Dylan Thomas uses symbols and images of nature to express how he feels towards death and childhood. He says that images are used to create a feeling of love towards life. Despite Dylan Thomas's obscure images, he expresses a clear message of religious devotion in many of his poems. The style of Dylan Thomas is an opaque poetic style which Thomas used to perfection. He possessed tremendous talent and was blessed with immense gifts that made him a professional success at a relatively young age.
\end{abstract}

Key words: Dylan Thomas, Romanticism, Poetic Style,

\section{Introduction}

Dylan Thomas is one of the writers who has often been associated with Welsh literature and culture in the last sixty years. He is possibly the most notable Welsh author. Fortunately, it is mainly his literary work, and not his tumultuous lifestyle, that is still associated with him. The analysis of some of his poems mirrors his sincere relationship to Wales.

Dylan Thomas was born in Swansea, Wales, in 1914. After he left school at the age of sixteen, he started working as a journalist in Swansea. In 1937, he married Caitlin MacNamara who gave birth to three children. These circumstances indicate a typical British, conservative and straightforward approach to family life. However, Dylan started drinking heavily, and Caitlin is rumoured to have had several extramarital affairs, even with colleagues and friends of her husband. Having moved to London, alcohol and indulgence were expensive for the young family, so they could not cover their costs anymore. Thus, in 1950, Thomas announced that he would emigrate to the United States because he thought he would be paid better there than in England. He settled in New York where he recited his works, and was profoundly admired. Nevertheless, the money he earned was spent on alcohol, which led his marriage with Caitlin into a serious crisis. On November 9, 1953, he died after a heavy drinking binge in a Manhattan hotel, at the age of 39. Later, Thomas's body was brought "home" to Wales. He was buried in the churchyard of Laugharne.

Dylan Thomas was influenced in his writing by the Romantic Movement from the beginning of the nineteenth century, and this can be seen in a number of his best works. Dylan Thomas uses symbols and images of nature to express how he feels towards death and childhood. He says that images are used to create a feeling of love towards life. Despite Dylan Thomas' often obscure images, he expresses a clear message of religious devotion in many of his poems. He creates images that reflect God's connection with the earth and body. In "And death shall have no dominion," Thomas portrays the redemption of the soul in death, and the soul's liberation into harmony with nature and God. Thomas associates God with thunder, rainbows, and night only to remind us that he is even more present in a simple stone as he is in other great entities. Colour imagery is also there in some of his poems as he describes his happiness as a child. He explains his young days as being as "happy as the grass is green."

The style of Dylan Thomas is an opaque poetic style, which Thomas uses to perfection. It is used to describe the unusual and day-to-day activities. Dylan Thomas possessed tremendous talent and was blessed with immense gifts that made him a professional success at a relatively young age; however, his personal life was often disappointing.

\section{Dylan Thomas romanticism:}

Romanticism is an aesthetic attitude born out of a late eighteenth century reaction to the Enlightenment, stressing powerful feelings, originality, the individual response and a return to nature. The Romantic period in English literature is usually considered to extend from 1798, when Wordsworth and Coleridge published their 
Lyrical Ballads, to 1832, when Sir Walter Scott died. The Romantic impulse extended beyond these dates, however, and can be seen in a variety of art forms, from the music of the latter half of the nineteenth century to the Romantic impulses of the Impressionists and post-Impressionists. The Romantic period was a turbulent era politically and socially as England was changing from its former status as an agricultural society to a modern industrial state where the balance of economic power shifted to large-scale employers. The French Revolution was another impetus for the development of the Romantic spirit, a spirit more egalitarian than the previous era.

Dylan Thomas was influenced in his writing by the Romantic Movement from the beginning of the nineteenth century, and this can be seen in a number of his best works, including the poems "Fern Hill," "A Refusal to Mourn the Death, by Fire, of a Child in London," and "Do Not Go Gentle into That Good Night." These and other Dylan works show the power of the Romantic style, which fit well with Thomas's interests and capabilities as a poet.

Poet Dylan Thomas was influenced in his writing by the Romantic Movement from the beginning of the nineteenth century, and this can be seen in a number of his best works, including the poems "Fern Hill," "A Refusal to Mourn the Death, by Fire, of a Child in London," and "Do Not Go Gentle into That Good Night." These and other Dylan works show the power of the Romantic style, which fit well with Thomas's interests and capabilities as a poet.

Attitudes and techniques typical of Romanticism dominate The Collected Poems of Dylan Thomas. Of these, the major elements are Thomas' view of himself as a member of society and as a creative artist, his use of auditory effects and visual imagery, and his exploration of the nature of the universe. It is the purpose of this study to show how, especially in these three aspects, the poetry fits into the Romantic tradition. Thomas' characteristic ambiguity makes categorization difficult; it often reaches the point of self-contradiction, as, for instance, when a seemingly orthodox religious statement proves on analysis to have an underlying sense that borders on disbelief. But the coexistence of such polarities reflects in itself a striving toward reconciliation of opposites that is a major Romantic characteristic. The expression of this striving took on changing tones over the twenty years of Thomas' poetic career, the concentration on inner processes that marked the early poems giving way to a general focus upon outer and more visible scenes in the later works. Neither of the emphasis, however, was exclusive to a single period of the poet's development; and in any case, the two concerns, as expressed by Thomas, are both Romantic. They merely represent different kinds of Romanticism.

Of the three major Romantic elements in Thomas' poems, the least prominent one is social concern. But the poems deal with affairs of the world more often than is readily apparent. Thomas' ambiguity obscures many of his political themes. Also, as several of the poems reveal, Thomas felt that he must preserve his artistic detachment or lose his effectiveness as a poet. Therefore, he chose to keep his work relatively untypical. The results were especially noticeable in the days when much of the recognized output of British poets was Marxist (Thomas published his first book of poetry in 1934). Although Thomas himself professed "rather elementary left-wing politics," no one has observed any appeal to "professional Marxists" in his poetry. And one writer in 1940 called Thomas "the most old-fashioned of his generation in his apparent separation of his poetry from his politics."

\section{Dylan Thomas as a metaphysical poet:}

Considering Dylan Thomas as a 'metaphysical poet' presents considerable difficulty because of the complexity of his poetry which does not fit into the frame work of any rigid definition. Pointing out an aspect specific in its connotation will be a hazardous task, as the essentiality paradoxical nature of his art might point towards the opposite of what one is seeking. A poet who has been described as a romantic who spearheaded the Neo Romantic movement in the 40's and as a metaphysical whose handling of religious themes is reminiscent in its salient features of that of the poets of the seventeenth century to whom that term has been applied would appear to be almost an impossibility, Dylan Thomas represents such as literary phenomenon whose poetry displays certain characteristics of the spontaneous lyrical outbursts of the romantics as well as the cerebral, rational, calculated elaborately worked out intellectual conundrums.

\section{Dylan Thomas as a creator of Death-Myth:}

The poetry of Dylan Thomas, in its own particular spectrality, also showcases a voice inflected by the presence and insertion of death and the death-image. For Sylvia Plath, the concept of the death-poet was both consciously fostered by her in poems, such as "Lady Lazarus", but also irreversibly solidified by the nature of her death by suicide, which for some readers, added the weight of a macabre authenticity. Dylan Thomas s poems are signified by a powerful death-myth, which emanates from the poet himself. The poems were originally crafted by Thomas with the presence of death always lurking, but when they were subsequently stamped with a "seal of authenticity" by his death amidst controversy and excess in America, Thomas himself became a spectral figure of death. Thomas's career being longer and more prodigious than Plath in reception, there are more opportunities in not only his poems, but also his stories, plays and film-scripts to find intriguing avenues for discovery. Thomas was a well-established writer when he died, but like Plath, his death, due to its 
mysterious nature, informs the way we read many of his poems, indeed how we read Dylan Thomas, as a character in his own drama. Death is the device by which Thomas crafted many of his most indelible and famous poems, and much like Plath, a spectral presence lurks in and around the poems. Not only was Thomas engaged in the crafting and living of his own myth, but in his image of what the Poet should be, he also upheld the truth value of that myth by dying in tragic circumstances at age 39. Like Sylvia Plath's suicide, the added presence of such a death causes spectral images to heavily upon the struggle of life versus death.

Dylan Thomas has not only been tied to death in his poems by their words, but the nature of their images. He helped foster and craft his own death-myth in his poems, but also fulfilled it, unwittingly or not, by dying far away in America, fueled by alcohol, sex, and a baffling assortment of strange circumstances. Dylan Thomas knew exactly which images he wanted to present to the world, and he was always conscious of how he would be perceived and received by everyone, from the layman to the university scholar. Dylan Thomas was not only crafting the mythology of death in his poems, but was actually living it. In Albert Camus "The Myth of Sisyphus", he writes: "a man defines himself by his make-believe as well as by his sincere impulses". Dylan Thomas wrote his poems specifically with his death, and the subsequent reception of his poetic death-image, in mind. Thomas s poems are extensions of the myth he was enacting, where he could link his "sincere impulses" with the extensive reaches of his "make-believe". Poems are where Thomas s perception of his myth is manually linked to the observations of nature, the earth, and of life and death. What becomes evident in Dylan Thomas is that he, like Plath, stressed the importance of the presence of death within the world. Though it is more exuberant and sweeping than what we have seen in Ariel by Sylvia Plath, it again shows that by both ruminating and living through death, Thomas, like Plath, actually celebrated life and believed in the power of humanity to persevere, and continue to produce

\section{Dylan Thomas's imagery:}

The intensity of any literary work largely depends on powerful imagination. It also depends on the effective execution of that very imagination in the pages of a literary work. Therefore, to visualise his/her imagination the poet/writer often employs various literary devices. The most effective and compelling of those is the use of imagery (a figure of speech). Imagery is used in literary works to refer to the ways the writers compose mental images in words. It signifies all the sensory perceptions used in a literary work, whether by literal description, allusion, simile, or metaphor. Imagery is not limited to visual imagery; it also includes auditory (sound), tactile (touch), thermal (heat and cold), olfactory (smell), gustatory (taste), and kinesthetic sensation (movement). Imagery engages the reader's imagination through wonderful descriptions or illustrations that vividly portray the reality of a particular moment. A literary work with effective imagery gives the reader a clear mental picture of what is happening and enhance what the writer is trying to convey to the reader.

Dylan Thomas is widely regarded as one of the 20th Century's most influential lyrical poets, and amongst the finest as such of all time. His acclaim is partly due to the force and vitality of his verbal imagery that is uniquely brilliant and inspirational. His vivid and often fantastic imagery was a rejection of the trends in the 20th Century poetics. While his contemporaries gradually altered their writing to serious topical verse, Thomas devoted himself to his passionately felt emotions. Thomas, in many ways, was more in alignment with the Romantics than he was with the poets of his era. He was considered the Shelley of the 20th century as his poems were the perfect embodiments of 'new-romanticism' with their violent natural imagery, sexual and Christian symbolism and emotional

Subject matter expressed in a singing rhythmical verse.

Dylan Thomas attached great importance to the use of imagery, and an understanding of his imagery is essential for an understanding of his poetry. Thomas' vivid imagery involved word play, fractured syntax, and personal symbolism. Thomas' poetic imagery shows the use of a mixture of several techniques, the most prominent being the surrealistic, imagistic, and metaphysical. But the bible, his study of Shakespeare and other English poets also laid under contribution. Thomas as a resourceful "language-changer", like Shakespeare, Dickens, Hopkins and Joyce, shaped the English language into a richly original mélange of rhythm, imagery and literary allusion. Here follows a brief discussion on Dylan Thomas' poetic imagery along with a critical inquiry into the major works by this poet:

\section{Dylan Thomas poetic style:}

Thomas claimed that his poetry was "the record of my individual struggle from darkness toward some measure of light... To be stripped of darkness is to be clean, to strip of darkness is to make clean." He also wrote that his poems "with all their crudities, doubts, and confusions, are written for the love of man and in praise of God, and I'd be a damned fool if they weren't." Passionate and intense, vivid and violent, Thomas wrote that he became a poet because "I had fallen in love with words." His sense of the richness and variety and flexibility of the English language shines through all of his work.

Thomas's verbal style played against strict verse forms, such as in the villanelle Do not go gentle into that good night. His images were carefully ordered in a patterned sequence, and his major theme was the unity 
of all life, the continuing process of life and death and new life that linked the generations. Thomas saw biology as a magical transformation producing unity out of diversity, and in his poetry he sought a poetic ritual to celebrate this unity. He saw men and women locked in cycles of growth, love, procreation, new growth, death, and new life again. Therefore, each image engenders its opposite. Thomas derived his closely woven, sometimes self-contradictory images from the Bible, Welsh folklore and preaching, and Freud. Thomas's poetry is notable for its musicality, most clear in poems such as Fern Hill, In Country Sleep, Ballad of the Long-legged Bait or In the White Giant's Thigh from Under Milkwood:

Who once were a bloom of wayside brides in the hawed house and heard the lewd, wooed field flow to the coming frost, the scurrying, furred small friars squeal in the dowse of day, in the thistle aisles, till the white owl crossed Thomas once confided that the poems which had most influenced him were Mother Goose rhymes which his parents taught him when he was a child:

Dylan Thomas was obsessed with words - with their sound and rhythm and especially with their possibilities for multiple meanings. This richness of meaning, an often illogical and revolutionary syntax, and catalogues of cosmic and sexual imagery render Thomas's early poetry original and difficult. In a letter to Richard Church, included by FitzGibbon in Selected Letters, Thomas commented on what he considered some of his own excesses: "Immature violence, rhythmic monotony, frequent muddle-headedness, and a very much overweighted imagery that leads often to incoherence." Similarly, in a letter to Glyn Jones, he wrote: "My own obscurity is quite an unfashionable one, based, as it is, on a preconceived symbolism derived from the cosmic significance of the human anatomy."

\section{Conclusion:}

Thomas' work and stature as a poet have been much debated by critics and biographers since his death. Critical studies have been clouded by Thomas' personality and mythology, especially his drunken persona and death in New York. Despite criticism by sections of academia, Thomas' work has been embraced by readers more so than many of his contemporaries, and is one of the few modern poets whose name is recognised by the general public. ${ }^{[158]}$ Several of his poems have passed into the cultural mainstream, and his work has been used by authors, musicians and film and television writers

\section{Acknowledgements}

I record a deep sense of gratitude to my Teacher and Research Supervisor Dr.A.Hari Prasanna, M.A.,M.Phil.,Ph.D., Professor, Department of English, S.V. University, Tirupathi. I am indebted to her for the concern, counsel and encouragement I have received from her both at personal and academic levels.

I also express my acknowledgement to the management, the Director and The H.O.D of Science and Humanities of N.B.K.R.I.S.T., Vidyanagar for their encouragement.

It is a real pleasure for me to express my indebtedness to my wife, my beloved mother and other family members for their care and encouragement.

I acknowledge the cooperation and assistance I have received from my friends and colleagues.

\section{References:}

\section{Journals}

[1] Anderson, M. Robert. "Thoma's 'A Refusal to Mourn...”" The Explicator. Vol.38, No.4 (Summer, 1980).

[2] Cox, C.B. "Dylan Thoma's 'Fern Hill'” The critical Quarterly. Vol.1, No.2 (Summer, 1959).

[3] Joshi, Neeta. "Influence of the Welsh Bardic Tradition in the Poetry of Dylan Thomas" Punjab University Research Bulletin. 21 (1990).

[4] Mckay, D.F. "Aspects of Energy in the Poetry of Dylan Thomas and Sylvia Plath" The Critical Quarterly. Vol.16, No.1 (Spring, 1974).

[5] Parshall, F. Peter “Thomas's The Force that Through the Green Fuse Drives the Flower”. The Explicator. Vol.29, No.8 (April, 1971).

[6] Press, John. "Dylan Thomas: A Refusal to Mourn...., Fern Hill, over Sir John's (September, 1967 ).

[7] Smith, A.J. “Ambiguity as Poetic Shift (Analysis of Dylan Thomas's 'Our Eunuch Dreams').” The Critical Quarterly. Vol.4, No.1 (Spring, 1962).

[8] Terrel, F. Caroll. “Thomas's Over sir John's Hill.” The Explicator. Vol.38, No.4 (Summer, 1980).

[9] Williams Anne. "Thomas's Over Sir John's Hill.” The Explicator. Vol.38, No.4 (Summer, 1980).

[10] Willis, Roger. "Dylan Thomas: Under Milk Wood." Notes on Literature. No.102 (January, 1970).

[11] Young, Allan. "Image as Structure: Dylan Thomas and Poetic Meaning." The Critical Quarterly. Vol. 17, No.4 (Winter 1975).

\section{Books}

[12] Blamires, Harry, ed. A Guide to Twentieth Century Literature in English. London: Methuen, 1983.

[13] Brinnin, Joh Malcolm. Dylan Thomas in America (An Intimate Journal). New York: Viking, 1957.

[14] Cecil, Lord David, ed. The Oxford Book of Christian Verse. Oxford: Clarendon, 1940.

[15] Cox, C.B, ed. Dylan Thomas: A Collection of Critical Essays. Englewood Cliffs : Prentice, 1966.

[16] Davies, Aneririn Talfan. Dylan: Druid of the Broken Body. Swansea: Salisbury, 1977.

[17] Davies, Walford. 'Dylan Thomas', Arts : A Third Course Twentieth Century Poetry. Unit 26, Keynes: The Open University Press, 1979. 
[18] Deutsch, Babette. Poetry in Our Time. New York: Columbia University Press, 1956

[19] Eliot, T.S. Selected Essays. London: Faber, 1951.

[20] Essays Ancient and Modern. London: Faber \& Faber, 1949

[21] Evans, B. Ifor. A Short History of English Literature. Great Britain: Penguin Books, 1958.

[22] Ferris, Paul. Dylan Thomas. London : Hodder and Stonghton, 1978

[23] Fitzgibbon, Constantine. The Life of Dylan Thomas. London: J.M. Dent, 1965

[24] James, Daniel. My Friend Dylan Thomas. London: J.M. Dent, 1977.

[25] Jones, Gwyn. The Oxford Book of Welsh Verse in English. New York: Oxford University Press, 1977.

[26] Kidder, M. Rushworth. Dylan Thomas: The Country of the Spirit. U.S.A: Princeton University Press, 1973.

[27] Kleinman, H.H. The Religious Sonnets of Dylan Thomas: A Study in Imagery and Meaning. Los Angeles: University of California Press, 1963.

[28] Lodge, David. The Modes of Modern Writing. London : Edward Arnold, 1971.

[29] Monro, Harolid. Twentieth Century Poetry. London: Chatto and Windus, 1950.

[30] Moynihan, T. William. The Craft and Art of Dylan Thomas. New York : Cornell University Press, 1966.

[31] Olson, Elder. The Poetry of Dylan Thomas. Chicago: University of Chicago, 1954

[32] Parry, Thomas. A History of Welsh Literature. Trans. Idris Bell, London: Oxford University Press, 1955.

[33] Pater, Walter. Appreciations. London: Macmillan, 1944.

[34] Singh, Brijraj, ed. Five Seventeenth Century Poets. New Delhi : OUP, 1992.

[35] Spender, Stephen. Since 1939, Drama, The Novel Poetry, Prose Literature. London : Longman, 1959.

[36] Tedlock, E.W, ed. Dylan Thomas: The Legend and the Poet. A Collection of Biographical and Critical Essays. London: William Heinemann, 1960.

[37] Trindall, W.Y. A Reader's Guide to Dylan Thomas. New York: Ferras and Straus Company, 1962.

[38] Traherne, Thomas. Centuries of Meditations. London: Dertram Dobell, 1908.

[39] Treece, Henry. Dylan Thomas : ‘Dog Among the Fairies', Rev. ed. London: Ernest Benn, 1959. 